\title{
PROCESY ZMIAN
}

FUNKCJONOWANIA PRZEDSIĘBIORSTW PRZEMYSLOWYCH

\author{
JACEK MAY \\ Łódź
}

\section{Adaptacja przedsiębiorstw przemysłowych - przyklad Lodzi}

\author{
PodstaWy TEORETYCZNE, ZAKRES I CELE BADAŃ
}

Od 1989 r. w łódzkim przemyśle następują zasadnicze zmiany wielkościowe, strukturalne i przestrzenne (por. m.in.: Jewtuchowicz 1993; Marczyńska-Witczak 1996; Markowski, Stawasz 1997; Markowski, Marszał 1999; Strategia... 1999; May 2000; Marczyńska-Witczak 2001; Marszał, May 2002). Zmiany te są m.in. wynikiem podejmowanych (albo niepodejmowanych) przez przedsiębiorstwa przemysłowe działań, adaptujących je do zmieniających się warunków gospodarowania.

Poniższe rozważania oparte są głównie na koncepcji adaptacji przestrzennej (m.in.: Walker 1975; Hamilton, Linge 1979; Grabher 1993). W niniejszej pracy zastosowano dynamiczne ujęcie adaptacji. Definiuje ono adaptację jako „zespół procesów przystosowawczych do zmian środowiska zewnętrznego i zachowań innych aktorów gry ekonomicznej” (Stryjakiewicz 1999, s. 36). Jednocześnie adaptację określają następujące atrybuty (Walker 1975): podmiot, czas, przestrzeń, warunki zewnętrzne, cel i mechanizm.

Podmiot, czas i przestrzeń adaptacji są określone w niniejszej pracy odpowiednio przez jej zakres przedmiotowy, przestrzenny i czasowy. Przedmiotem badań jest 350 zakładów przemysłowych różnej wielkości, zlokalizowanych w granicach administracyjnych Łodzi. Wśród badanych przedsiębiorstw 45 zatrudniało powyżej 20 pracowników. Zakres czasowy badań obejmuje lata 1992-2003.

Cele adaptacji były zmienne w czasie. W latach 1989-1992 obejmowały one przetrwanie szoku transformacyjnego i uzdrowienie sytuacji ekonomicznej firm (por. m.in.: Jewtuchowicz 1993; Markowski, Stawasz 1997; Markowski, Marszał 1999; Stryjakiewicz 1999; Marszał, May 2002). Do realizacji tych celów niezbędne było pozyskanie środków inwestycyjnych, najczęściej przez prywatyzację przedsiębiorstw państwowych. Od 1992 roku podejmowano działania zwiększające konkurencyjność przedsiębiorstw i ich adaptabilność, czyli zdolność do ciągłej adaptacji (Grabher 1993).

Powyższe cele próbowano osiąnąć, stosując mechanizmy obejmujące różne strategie adaptacyjne. Strategie przestrzenne oraz takie strategie aprzestrzenne, które mają skutki przejawiające się w wymiarze przestrzennym, D.F. Walker (1975) nazywa adaptacja przestrzennq. Różne rodzaje strategii adaptacyjnych zostały zidentyfikowane na podstawie wielu źródeł przez T. Stryjakiewicza (1999). Systematykę działań adaptacyjnych podają również J. Michalak i U. Dzika (2000), przy czym nazywają oni te działania restrukturyzacyjny- 
mi. T. Stryjakiewicz (1999) stworzył również typologię form adaptacji przestrzennej przedsiębiorstw przemysłowych do zmieniających się warunków gospodarowania. Oparł się on na modelu sposobów regulacji przedsiębiorstwa B.T. Asheima i T. Heraldsena (1991) oraz A. Smitha (1995). Model ten próbuje połączyć teorię regulacji (m.in.: Aglietta 1979; Boyer 1990), koncepcję terytorialnego wyposażenia społecznego (Granovetter 1985) i teorię sieci przemysłowych (m.in.: Conti 1993; Håkansson, Johanson 1993).

Niniejszy artykuł ma dwa cele. Celem pierwszym, poznawczym, jest identyfikacja i próba usystematyzowania strategii adaptacyjnych podejmowanych przez łódzkie przedsiębiorstwa przemysłowe w latach 1992-2003. Drugim celem, teoretycznym, jest próba zastosowania wspomnianej typologii form adaptacji T. Stryjakiewicza (1999) do syntezy zidentyfikowanych strategii adaptacyjnych. Dane wyjściowe pochodzą z przeprowadzonych wywiadów kwestionariuszowych, kwerendy prasowej oraz ze stron internetowych badanych przedsiębiorstw.

\section{STUDIA PRZYPADKÓW}

Spośród przedsiębiorstw będących przedmiotem badań, 15 potraktowano jako studia przypadków. Stosowane w tych przedsiębiorstwach strategie adaptacyjne były najbardziej różnorodne albo charakterystyczne dla danej branży. Siedem z tych przedsiębiorstw, o zatrudnieniu ponad 100 osób, nazwano przedsiębiorstwami dużymi. Pozostałe były przedsiębiorstwami średniej wielkości i zatrudniały od 21 do 100 pracowników ${ }^{1}$.

Przedsiębiorstwem, w którym zastosowano różnorodne i głębokie działania adaptacyjne, są Zakłady Transformatorów ABB Elta Sp. z o.o. ${ }^{2}$. W 1991 roku państwowe przedsiębiorstwo Elta zostało sprzedane szwajcarsko-szwedzkiemu koncernowi Asea Brown Boveri. W pierwszym etapie adaptacja polegała na redukcji zatrudnienia oraz likwidacji filii i eksternalizacji zbędnych działów produkcyjnych. W 1993 roku zlikwidowano filię przy ulicy Gdańskiej 138, reaktywując firmę Woltan Sp. z o.o., istniejącą w tym miejscu do 1958 roku. Drugim etapem adaptacji była twarda restrukturalizacja. Polegała ona na remontach biur i hal produkcyjnych, wymianie parku maszynowego oraz zmianie ustawienia ciagów technologicznych w przestrzeni zakładu (zmiany lay out machine). Ciagi technologiczne i komunikacyjne zostały ustawione potokowo i nie krzyżowały się ze sobą. Konsekwencją tych zmian było usprawnienie procesu produkcji i zarządzania oraz poprawa wydajności. Zaoszczędzono również 45\% powierzchni produkcyjnej. Umożliwiło to wydzierżawienie terenów innym firmom powstałym z udziałem ABB, tj. AD Tranz, ABB Elpar, ABB ZWAR, ABB Elwy, ABB Kent-Metr.

Kolejnym etapem adaptacji była miękka restrukturalizacja. Obejmowała ona zmiany struktury zarządzania i zmiany organizacyjno-finansowe. Zastosowano model będący standardem w firmach należących do grupy ABB.

\footnotetext{
${ }^{1} \mathrm{Na}$ ogół przyjmuje się, że duże przedsiębiorstwa przemysłowe zatrudniają od 250 albo 500 pracowników. Przyjęta w artykule inna klasyfikacja wielkościowa jest bardziej dostosowana do sytuacji ekonomicznej i struktury przemysłu w Łodzi (por. Marszał, May 2002).

${ }^{2}$ Wszystkie informacje na temat przedsiębiorstwa ABB Elta Sp. z. o.o. uzyskano podczas wywiadu kwestionariuszowego z dyrektorem Eugeniuszem Jaworskim.
} 
Zarządzanie przedsiębiorstwem podzielono na cztery segmenty i dla każdego z nich opracowano strategię i plan działania rok po roku. Segmentami tymi były:

1) zarządzanie dostawami i selekcja dostawców według kryterium jakości;

2) marketing, obejmujący m.in. tworzenie przedstawicielstw regionalnych;

3) zarządzanie zasobami ludzkimi i szkolenie pracowników3;

4) usprawnianie procesów administracyjnych i produkcyjnych.

Zmiany organizacyjno-finansowe polegały na zastapieniu systemu silosowego systemem centrów zysku.

W systemie silosowym przedsiębiorstwo miało strukturę hierarchiczną. Poszczególne elementy łańcucha produkcji (zaopatrzenie, produkcja poszczególnych grup wyrobów, zbyt, technologia, obsługa urządzeń) tworzyły odpowiednie działy (silosy). Nie istniał wspólny cel przedsiębiorstwa, lecz jedynie cele cząstkowe dla poszczególnych działów formułowane na szczeblu dyrekcji naczelnej. Przepływ informacji był pionowy, w dół hierarchii organizacyjnej. Nie było przepływu informacji pomiędzy działami. Podobnie zorganizowane były jednostki organizacyjne niższego rzędu. Działy podlegały wspólnemu dyrektorowi i miały wspólny bilans. Z tego względu nie było informacji o dochodowości poszczególnych działów.

W systemie centrów zysku organizacja firmy ma strukturę poziomą. Poszczególne działy (centra zysku) przypominają odrębne zakłady. Między nimi istnieje poziomy przepływ informacji. Poszczególne działy realizują wspólne cele, sformułowany przez zarząd firmy. Pomimo wspólnej księgowości dla całego przedsiębiorstwa, bilanse są wykonywane odrębnie dla każdego działu. W przypadku długotrwałych strat przynoszonych przez dział, zostaje on restrukturalizowany albo likwidowany. W tym ostatnim przypadku, jego zadania zostają przekazane na zewnątrz na zasadzie eksternalizacji produkcji albo outsourcingu.

Następne dwa przykłady działań adaptacyjnych dotyczą ZPB Uniontex S.A. i ZPB Rena-Kord S.A. Obydwa przedsiębiorstwa reprezentują przemysł włókienniczy, dominujący w Łodzi przed 1989 rokiem. Obydwie firmy były przedsiębiorstwami państwowymi. Po redukcjach zatrudnienia przekształcono je w jednoosobowe spółki Skarbu Państwa (JSSP). Następne działania adaptacyjne obejmowały dalsze redukcje zatrudnienia i ograniczanie zajmowanych powierzchni produkcyjnych. ZPB Rena-Kord S.A. sprzedały dwa z posiadanych trzech zakładów. Jeden z nich firma Atlas S.J. przeznaczyła na swoją siedzibę, a w drugim montaż wyrobów rozpoczęła firma Bosch-Siemens Hausgerate Gmbh. W przypadku ZPB Uniontex sprzedano tereny dawnych Zakładów Ludwika Grohmana przy ulicy Targowej i Tylnej. Znajduje się tam obecnie kompleks „Centrum” Łódzkiej SSE. Część głównej tkalni została natomiast wydzierżawiona małym i średnim firmom.

Działania adaptacyjne omawianych firm ograniczyły się do opisanych wyżej strategii. Nie usprawniono procesów zarządzania i produkcji przez zmiany organizacyjno-finansowe, modernizację parku maszynowego i technologii. Wysokie koszty produkcji, import taniej bawełny z Dalekiego Wschodu oraz niska jakość wyrobów utrudniały ich zbyt na rynku polskim. Z przyczyn politycznych i ekonomicznych załamały się również kontakty z tradycyjnym rynkiem państw poradzieckich (por. m.in.: Marczyńska-Witczak 1996; Markowski, Stawasz 1997; Markowski, Marszał 1999; Strategia... 1999; Marszał, May 2002). Niezastosowanie przez opisywane przedsiębiorstwa działań marketingowych również przyczyniło się do zmniejszenia produkcji sprzedanej. Konsekwencją było zmniejszanie produkcji, redukcja zatrudnienia i praktyczna likwidacja obu przedsiębiorstw.

\footnotetext{
${ }^{3}$ W 1999 roku na szkolenia wydano w ABB Elta 400 tys. USD.
} 
Kolejne dwie firmy: Femina S.A. i Dresso-Invest S.A., reprezentują przemysł dziewiarski. Przed 1989 rokiem były one przedsiębiorstwami państwowymi. Przedsiębiorstwo Femina S.A. zostało sprywatyzowane przez likwidację w 1995 roku i przekształcone w JSSP. Po 1997 roku zostało ono wykupione przez prywatnego inwestora. Pomimo prywatyzacji zakłady te zmniejszały jednak produkcję i zatrudnienie oraz sprzedawały swój majątek produkcyjny, w tym tereny i budynki, małym firmom prywatnym oraz Urzędowi Miasta Łodzi. Jedynym działaniem adaptacyjnym była próba outsourcingu w postaci wydzielenia w 1999 roku farbiarni i utworzenia zależnego przedsiębiorstwa Femina-Kolor.

Zakłady Dresso w 1994 roku zostały sprzedane przedsiębiorcy polonijnemu i zmieniono ich nazwę na Dresso-Invest S.A.. Tak jak w przypadku zakładów Femina S.A., działania adaptacyjne objęły jedynie redukcję zatrudnienia, ograniczenie zajmowanych powierzchni produkcyjnych i wyodrębnienie farbiarni. Utworzono przedsiębiorstwo Dresso-Color, a zbędne budynki wynajęto wielu małym i średnim firmom produkcyjnym.

Brak innych działań adaptacyjnych w obydwu przedsiębiorstwach doprowadził, podobnie jak w przypadku zakładów Uniontex S.A. i Rena-Kord S.A., do praktycznej likwidacji firm. Obecnie wynajmują one dawne powierzchnie produkcyjne.

Odmienną drogę adaptacji niż w powyżej opisanych przypadkach przyjęło dawne państwowe przedsiębiorstwo przemysłu dziewiarskiego Olimpia S.A. Jeszcze jako przedsiębiorstwo państwowe zredukowało ono zatrudnienie i zlikwidowało filię przy ulicy Piotrkowskiej. Działalność firmy kontynuowano w nowym budynku przy ulicy Obywatelskiej 137. W 1996 roku zakłady przekształcono w JSSP Olimpia S.A., a w 1998 roku odsprzedano część akcji prywatnym inwestorom. Poszukując rynków zbytu przedsiębiorstwo rozpoczęło przerób uszlachetniony dla firm Hugo Boss i Enzo Lorenzo. Jednocześnie w firmie tworzono własne projekty odzieży. Współpraca z firmami zagranicznymi umożliwiła sprzedaż w Niemczech i we Włoszech własnych wzorów pod nazwami obcych marek. Sprzedaż wyrobów pod własną marką w Polsce jest możliwa dzięki działaniom marketingowym i sieci sklepów firmowych. Jednocześnie firma podejmuje udane próby odzyskania dawnych rynków zbytu w Czechach, Bułgarii i na Węgrzech.

Przykładami dawnych dużych przedsiębiorstw państwowych, które produkują odzież wysokiej jakości są: Próchnik S.A. produkujący ciężką odzież męską i Wólczanka S.A. produkująca koszule, bluzki i żakiety ${ }^{4}$. Obydwa przedsiębiorstwa zostały objęte procesami prywatyzacji w 1990 roku. Na początku okresu transformacji dysponowały one dobrze rozwiniętymi działami projektowymi, własną siecią sprzedaży i znaną na polskim rynku marką.

Pierwszymi działaniami adaptacyjnymi firmy Próchnik S.A. były działania ograniczające koszty i dostosowujące potencjał produkcyjny do zmniejszonej wielkości produkcji. Działania te objęły zmniejszenie zatrudnienia i relokację całej firmy z Al. Rydza-Śmigłego 20 na ulicę Kilińskiego 228. Ponadto działania adaptacyjne polegały na projektowaniu własnych wzorów odzieży wysokiej jakości, działaniach marketingowych i utrzymywaniu sieci sklepów firmowych w Polsce oraz przerobie uszlachetnionym dla firmy Hugo Boss.

Jednocześnie Próchnik S.A. rozpoczął budowanie grupy kapitałowej przejmując trzy rodzaje przedsiębiorstw przemysłu tekstylnego:

- produkujący gotową odzież z dzianin Jarlan z Jarosławia;

- produkujące wyroby metrażowe: Bizuna z Białegostoku, Dolwis z Leśnej koło Lubania i Miranda z Turku;

${ }^{4}$ Informacje na temat przedsiębiorstw Próchnik S.A. i Wólczanka S.A. pochodzą z wywiadów przeprowadzonych w firmach oraz z cytowanej literatury. 
- produkujące wyroby dekoracyjne: Koronki z Brzozowa i Wisan ze Skopania (produkcja firanek).

Próchnik S.A. starał się scalić wszystkie spółki grupy i połączyć ich majątki produkcyjne. Firmy miały mieć wspólną sieć sprzedaży, dział handlowy i dostawców. Strategię rozwoju grupy miał tworzyć zarząd. Jego zadaniem było m.in. przejmowanie nowych firm branży tekstylnej. Likwidacja odrębnych zarządów i rad nadzorczych, połączenie wyspecjalizowanych służb i zmniejszenie zatrudnienia z ok. 6300 do ok. 4540 osób, miało zaoszczędzić $27 \mathrm{mln}$ zł. Jednocześnie sprzedaż gruntów, budynków i niewykorzystanych maszyn miała przynieść ok. 20 mln zł zysku (Margas 1998).

Powyższe działania nie poprawiły jednak sytuacji ekonomicznej Próchnik S.A. GK i jej spółki wiodącej. Wyniki finansowe zarówno Grupy, jak i przedsiębiorstwa Próchnik S.A. wynosiły w 2002 roku po ok. -26 000 tys. zł („Rzeczpospolita” nr 287, 10.12.2002). Przyczyn takiej sytuacji należy szukać w złym zarządzaniu (por. Torański 2002b). Struktura organizacyjno-finansowa Grupy Kapitałowej i firmy Próchnik S.A. jest zbyt hierarchiczna i scentralizowana. Brakuje w niej powiązań poziomych, co uniemożliwia elastyczną organizację produkcji. Ponadto główne cele tworzenia grupy kapitałowej osiaga się najczęściej poprzez zróżnicowanie branżowe lub włączenie albo stworzenie przedsiębiorstw wspomagających branże kluczowe dla grupy (por. Stryjakiewicz, Wajda 2003). Tymczasem spółki tworzące Próchnik S.A. GK reprezentowały podobne branże i były słabe ekonomicznie.

Przedsiębiorstwo Wólczanka S.A. dysponowało początkowo pięcioma zakładami w Łodzi, Poddębicach, Wieruszowie, Opatowie i Ostrowcu Świętokrzyskim. Zmniejszenie kosztów produkcji próbowano osiąnnąć modernizacją maszyn i zmianami organizacyjnymi. Niechętnie redukowano zatrudnienie, ponieważ stało to w sprzeczności z przyjętym wizerunkiem firmy przyjaznej dla społeczności lokalnych. Wizerunek ten był częścią strategii marketingowej przedsiębiorstwa. W 1998 roku sprzedano jednak zakład w Poddębicach, a w roku 2005 spółka planowała sprzedaż zakładów w Wieruszowie i Opatowie ze względu na zbyt duże straty.

W celu zwiększenia rynku zbytu przedsiębiorstwo, oprócz działań marketingowych, zaczęło projektować nie tylko wyroby eleganckie, ale również kolekcje przeznaczone dla młodzieży i grup mniej zamożnych klientów. Próbą wejścia na rynki Europy Zachodniej było podjęcie przerobu uszlachetnionego, m.in. marki Walbusch. W sieciach sprzedaży tej firmy i pod jej marką, Wólczanka sprzedaje również własne kolekcje. W 2001 roku rozpoczęto przygotowania do wejścia na rynek brytyjski z własnymi wyrobami i z własną marką (Torański 2002a).

Od 2000 roku przedsiębiorstwo rozpoczęło tworzenie Grupy Kapitałowej. Grupa ta obejmuje tylko przedsiębiorstwo wiodące Wólczanka S.A. oraz firmę WLC INVEST Sp. z o.o. Ma ona zajmować się inwestycjami kapitałowymi, m.in. w branży teleinformatycznej. Od 1998 roku Wólczanka planuje połączenie się z inną firmą odzieżową Vistula S.A. Na razie prowadzi z nią wspólną sprzedaż niektórych luksusowych wyrobów, promując markę Lantier. W planach jest również rozszerzenie grupy poprzez wspólny z Vistulą S.A. zakup innych firm odzieżowych Warmia i Polo (Margas 1998).

Pomimo powyższych działań, w 2002 r. Wólczanka S.A. i Wólczanka S.A. GK miały przychody odpowiednio 94337 tys. zł i 98531 tys. zł. Jednocześnie Wólczanka S.A. GK przyniosła stratę -4929 tys. zł, a Wólczanka S.A. niewielki zysk 1115 tys. zł („Rzeczpospolita” nr 287, 10.12.2002). Przyczyną były błędy w zarządzaniu oraz przynoszące straty inwestycje kapitałowe firmy WLC INVEST. 
Po 1989 roku szybko rozwijała się w Łodzi grupa odzieżowych firm średniej wielkości. Jej reprezentantami są zakłady Ola Styl Studio oraz Hexeline. Obydwie firmy produkuja damską odzież wysokiej jakości, przy czym Ola Styl Studio szyje wyroby przeznaczone dla młodzieży, a Hexeline odzież wizytowa.

W obydwu firmach projektowaniem kolekcji zajmowali się właściciele. Starając się nadążać za modą światową w zakresie wzornictwa i materiałów, zwracali oni uwagę na potrzeby rynku polskiego. Jednocześnie firmy te próbowały wejść na rynki zagraniczne. Eksport do Stanów Zjednoczonych stanowił 8\% produkcji sprzedanej firmy Ola Styl Studio. Zakład Hexeline posiadał własne sklepy w Rosji i eksportował do Szwecji i Holandii. Eksport stanowił $12 \%$ produkcji sprzedanej firmy.

Powyższe działania i elastyczna organizacja produkcji umożliwiły opisywanym przedsiębiorstwom rozwój do ok. 2002 roku. Od roku 2003 firmy te przeżywają trudności ekonomiczne związane z barierą popytu i niską rentownością produkcji.

Nietypową firmą dla łódzkiej gospodarki jest Redan S.A. ${ }^{5}$. Firma zajmuje się projektowaniem, produkcją i marketingiem odzieży. Od 1995 roku buduje ona od podstaw grupę kapitałową. Grupa Redan składa się z 25 spółek, w których Redan S.A. ma 100\% udziałów lub jest podmiotem dominującym. Ponadto do grupy należy jedna spółka stowarzyszona „Top Mark” sp. z o.o., w której Redan S.A. posiada 45\% udziałów. Spółki zależne wspomagają branże kluczowe grupy albo odpowiadają za projektowanie, produkcję i zarządzanie sieciami sprzedaży produktów konkretnej marki. Najważniejsze dla grupy marki to: Top Secret, Troll, Adesso Fashion oraz Happy Kids.

Poszczególne marki są przeznaczone dla grup klientów zróżnicowanych pod względem płci, wieku, gustów i możliwości finansowych. Sieć sprzedaży grupy Redan składa się z czterech podstawowych segmentów:

1) sieci sklepów marki Top Secret: 8 za granicą i 81 w Polsce, zlokalizowanych w miastach powyżej 40 tys. mieszkańców, najczęściej w galeriach handlowych;

2) sieci sklepów marki Troll: $81 \mathrm{w}$ Polsce i 5 za granica, zlokalizowanych w miastach powyżej 50 tys. mieszkańców, przy głównych ulicach handlowych;

3) sieci 113 samoobsługowych dyskontów Textil Market znajdujących się przy ulicach handlowych lub w domach handlowych małych i średnich miast;

4) sprzedaży w hipermarketach i w sieciach dyskontowych.

Ponadto od 2006 roku grupa Redan tworzy sieć ekskluzywnych sklepów. Sprzedaje w niej, na zasadzie wyłączności w Polsce, odzież francuskiej firmy MORGAN oraz luksusowe wyroby odzieżowe i galanterię innych firm. Dalsza strategia rozwoju przedsiębiorstwa zakłada stworzenie sieci sprzedaży za granica, w pierwszej kolejności na Litwie, Łotwie, w Estonii, w Niemczech, Czechach i na Słowacji.

Struktura przestrzenna łańcucha produkcji grupy Redan jest zorganizowana na zasadach elastycznej organizacji produkcji. Najbardziej dochodowe elementy, oparte na wiedzy, takie jak projektowanie i marketing znajdują się w Polsce. Elementy pracochłonne są zlokalizowane w Chinach z powodu niskich kosztów pracy.

Po 1989 roku w strukturze przemysłu łódzkiego zaczęło wzrastać znaczenie przemysłu kosmetycznego i przemysłu materiałów budowlanych (por. Marszał, May 2002). Reprezentantami przemysłu kosmetycznego są firmy Kolastyna, Loki i Venita, a przemysłu materiałów budowlanych przedsiębiorstwo Atlas S.J.

\footnotetext{
${ }^{5}$ Informacje nt. grupy Redan S.A. pochodzą ze stron www.redan.com.pl i www.biznes.pl.
} 
Wymienione firmy kosmetyczne reprezentowały początkowo tzw. przemysł garażowy. Po osiagnięciu powodzenia ekonomicznego następowała ich relokacja na istniejące tereny przemysłowe albo do nowo budowanego zakładu. Ponadto Kolastyna przeniosła większą część produkcji do Krakowa. Powodem był rozwój firmy i możliwość wykorzystania infrastruktury po zakładach Pollena-Miracullum. W Łodzi pozostała siedziba firmy, laboratoria oraz działy marketingu i projektowania.

Strategie marketingowe poszczególnych firm zakładały dotarcie z produktami do odmiennych grup klientów. Grupy te są zróżnicowane pod względem wymagań jakościowych, zamożności i potrzeb. Firmy Venita i Loki wytwarzają środki higieny i niektóre kosmetyki upiększające niskiej i średniej jakości. Kolastyna produkuje głównie kosmetyki upiększające, przeznaczone dla klientów bardziej zamożnych, o większych wymaganiach jakościowych.

Ostatnią omawianą firmą jest Atlas S.J. ${ }^{6}$ produkujący wyroby chemii budowlanej. Rozpoczynając działalność jako firma garażowa wykorzystała ona lukę rynkową. W połowie lat dziewięćdziesiątych XX w. Atlas miał około $90 \%$ udziałów w polskim rynku zapraw i klejów budowlanych. Rozwój innych firm tego segmentu oraz import spowodowały spadek udziału w rynku do 60\% w 2005 roku. Właściciele firmy uważają, że sukcesem będzie utrzymanie ok. 40-50\% udziału w rynku.

Firma początkowo podrabiała produkty zagraniczne. Następnie imitację zastąpiono produkcją własnych wyrobów. Od początku działalności Atlas prowadził intensywne działania marketingowe, budując pozycję swojej marki. Służyły temu agresywne kampanie reklamowe, jakość wyrobów oraz sponsorowanie przedsięwzięć kulturalno-artystycznych i sportu. Firma zbudowała własną sieć sprzedaży tworząc działy handlowe i Regionalne Centra Doradztwa Budowlanego w każdym województwie. Centra te są przeznaczone dla klientów instytucjonalnych i indywidualnych. Ich działalność obejmuje m.in. pomoc w rozwiązywaniu problemów oraz szkolenie klientów w zakresie używania produktów firmy.

Pod koniec lat dziewięćdziesiątych XX w. Atlas zaczął wkraczać na rynki zagraniczne, eksportując do Holandii i Portugalii. Sieci sklepów i centra doradztwa budowlanego stworzono na Litwie, w Rosji, Łotwie, Ukrainie, Białorusi, Estonii, Czechach, Słowacji, Holandii i Portugalii. Eksport stanowi 6\% produkcji sprzedanej firmy. Następnym etapem ekspansji jest budowa własnych zakładów produkcyjnych. Pierwszym z nich jest inwestycja w Dubnej pod Moskwą.

Od 1991 r. budowana jest od podstaw Grupa Atlas. Składa się ona z dwudziestu sześciu przedsiębiorstw. W strukturze grupy dominuje działalność nieprodukcyjna. Reprezentują ją regionalne działy handlowe, niekiedy połączone z produkcją, Centra Doradztwa Budowlanego i dział marketingu (w Gdańsku). Trzy zakłady: w Łodzi, w suwalskiej SSE (Atlas-Wigry) i w legnickiej SSE (Atlas-Sudety) ${ }^{7}$, są zakładami czysto produkcyjnymi. Grupa posiada również własną bazę surowcową. Należy do niej pięć kopalń surowców skalnych w Sudetach i regionie świętokrzyskim, m.in. kopalnia piasku Grudzeń Las i gipsu Nida Gips.

${ }^{6}$ Informacje na temat przedsiębiorstwa Atlas S.J. pochodzą z wywiadu przeprowadzonego z panem Grzegorzem Grzelakiem, prezesem Atlas S.J. oraz ze strony www.atlas.com.pl.

${ }^{7}$ Ustawa z 20.10.1994 r o specjalnych strefach ekonomicznych przewiduje ulgi podatkowe tylko dla nowej firmy utworzonej na obszarze SSE. 


\section{SYSTEMATYKA DZIAŁAŃ ADAPTACYJNYCH}

Przedstawioną poniżej systematykę działań adaptacyjnych oparto na ustaleniach T. Stryjakiewicza (1999) oraz M.J. Michalaka i U. Dzikiej (2000). Rozpoznano 18 rodzajów strategii, które pogrupowano w pięć typów (tab. 1). Jednocześnie starano się zidentyfikować rodzaje przedsiębiorstw, które najczęściej stosowały poszczególne rodzaje strategii adaptacyjnych.

W okresie szoku transformacyjnego, celem adaptacji łódzkich przedsiębiorstw przemysłowych było przetrwanie w warunkach stworzonych przez gospodarkę rynkową i barierę efektywnego popytu. Podejmowane działania zmniejszały koszty produkcji poprzez redukcję zatrudnienia oraz pozbywanie się zbędnego majątku produkcyjnego i obiektów socjalnych (por. tab. 1; Stryjakiewicz 1999). Ze względu na dużą liczbę przedsiębiorstw wielozakładowych, zwłaszcza w przemyśle włókienniczym, częstym rodzajem strategii tego typu była likwidacja filii.

Pierwszy typ strategii adaptacyjnych pozwalał zwiększyć wydajność pracy w przedsiębiorstwie, dostosować jego potencjał do wielkości produkcji oraz usprawnić jego zarządzanie i organizację. Omawiany typ strategii był stosowany zarówno przez przedsiębiorstwa państwowe, przedsiębiorstwa w trakcie prywatyzacji, jak i przez firmy prywatne. W przypadku przedsiębiorstw państwowych opisywane działania były przygotowaniem do prywatyzacji, Redukcja kosztów nie zapobiegła jednak likwidacji łódzkich zakładów włókienniczych.

Drugim typem strategii adaptacyjnych była relokacja zakładów. Najczęściej były to relokacje wewnątrzmiejskie. Przypadki relokacji zewnętrznych (delokacji) były nieliczne i dotyczyły tylko przedsiębiorstw dużych. W zależności od przyczyn wyróżniono relokacje: rozwojową, ratunkową i sukcesyjną.

Przyczyną relokacji rozwojowej był rozwój przedsiębiorstwa. Wymagało to większych i lepiej wyposażonych powierzchni produkcyjnych, zaplecza logistycznego i dobrej dostępności komunikacyjnej. Niekiedy czynnikiem relokacji były niższe koszty pracy, ale ich zmniejszenie wpływało na jakość wyrobów. Relokację ratunkową stosowały natomiast przedsiębiorstwa w złej sytuacji finansowej, ograniczające zatrudnienie i produkcję. Firmy te poprzez zmianę lokalizacji starały się znacznie zmniejszyć koszty. Nowe miejsca lokalizacji charakteryzowały się jednak gorszym wyposażeniem infrastrukturalnym lub mniejszymi kwalifikacjami siły roboczej. Wpływało to negatywnie na jakość i wielkość produkcji, co najczęściej prowadziło do likwidacji firmy.

Relokacja sukcesyjna przypomina biologiczny mechanizm konkurencji, inwazji i sukcesji. Ten rodzaj relokacji dotyczy małych i niekiedy średnich firm, które były lokalizowane na najbardziej atrakcyjnych w mieście terenach przemysłowych. Atrakcyjność tych terenów spowodowała inwazję, a następnie sukcesję przedsiębiorstw o dużym potencjale ekonomicznym. Firmy słabsze, nie mogąc sprostać konkurencji, szukały tańszych powierzchni produkcyjnych. Przy czym wyposażenie infrastrukturalne miejsc nowych lokalizacji było gorsze niż miejsc pierwotnych, ale nadal wystarczające. Ponadto, w odróżnieniu od lokalizacji ratunkowej, gorsza jakość nowych terenów nie wpływała na zmniejszenie jakości i wielkości produkcji. 
Tabela 1. Systematyka działań adaptacyjnych łódzkich zakładów przemysłowych

\begin{tabular}{|c|c|c|}
\hline $\begin{array}{l}\text { Typ } \\
\text { strategii }\end{array}$ & Rodzaj strategii & $\begin{array}{l}\text { Przedsiębiorstwa najczęściej stosujące } \\
\text { dany rodzaj strategii adaptacyjnych }\end{array}$ \\
\hline \multirow[t]{3}{*}{ Redukcja kosztów } & Redukcja zatrudnienia & \multirow{3}{*}{$\begin{array}{l}\text { państwowe } \\
\text { - w trakcie prywatyzacji } \\
\text { - nowo sprywatyzowane } \\
\text { • prywatne, powstałe po } 1989 \text { roku, z kapitałem } \\
\text { różnego pochodzenia }\end{array}$} \\
\hline & $\begin{array}{l}\text { Ograniczenie zajmowa- } \\
\text { nych terenów i budynków; } \\
\text { likwidacja filii }\end{array}$ & \\
\hline & $\begin{array}{l}\text { Sprzedaż zbędnych ma- } \\
\text { szyn i urządzeń }\end{array}$ & \\
\hline \multirow[t]{3}{*}{ Relokacja } & Rozwojowa & $\begin{array}{l}\text { - z kapitałem zagranicznym } \\
\text { • duże i średnie prywatne firmy polskie }\end{array}$ \\
\hline & Ratunkowa & \multirow[t]{2}{*}{ - przedsiębiorstwa polskie różnej wielkości } \\
\hline & Sukcesyjna & \\
\hline \multirow{6}{*}{ 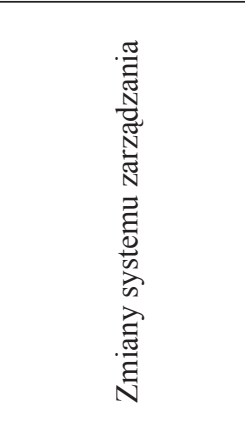 } & Organizacja marketingu & \begin{tabular}{|l|} 
- z kapitałem zagranicznym \\
• duże i część średnich prywatnych firm polskich
\end{tabular} \\
\hline & $\begin{array}{l}\text { Elastyczne formy orga- } \\
\text { nizacji produkcji, w tym } \\
\text { zatrudnienia }\end{array}$ & $\begin{array}{l}\text { - prywatne, różnej wielkości i pochodzenia kapi- } \\
\text { tału }\end{array}$ \\
\hline & Twarda restrukturalizacja & \multirow{2}{*}{$\begin{array}{l}\text { - z kapitałem zagranicznym } \\
\text { • większość dużych prywatnych firm polskich }\end{array}$} \\
\hline & Miękka restrukturalizacja & \\
\hline & $\begin{array}{l}\text { Eksternalizacja produkcji, } \\
\text { outsourcing, spin off }\end{array}$ & \begin{tabular}{|l}
$\cdot$ w trakcie prywatyzacji \\
$\cdot$ nowo sprywatyzowane
\end{tabular} \\
\hline & $\begin{array}{l}\text { Tworzenie grup kapitało- } \\
\text { wych }\end{array}$ & - duże prywatne firmy polskie \\
\hline \multirow{3}{*}{$\begin{array}{l}\text { Zmiany struktury } \\
\text { produkcji }\end{array}$} & Ograniczenie asortymentu & - duże i średnie prywatne firmy polskie \\
\hline & $\begin{array}{l}\text { Nowoczesne wzornictwo } \\
\text { i technologie; wzrost } \\
\text { jakości }\end{array}$ & $\begin{array}{l}\text { - duże i średnie prywatne firmy polskie } \\
\text { - z kapitałem zagranicznym }\end{array}$ \\
\hline & Przerób uszlachetniony & $\begin{array}{l}\text { • różnej wielkości firmy polskie, głównie odzie- } \\
\text { żowe }\end{array}$ \\
\hline \multirow{3}{*}{$\begin{array}{c}\text { Stałe kontakty } \\
\text { z partnerami } \\
\text { zagranicznymi }\end{array}$} & Zagraniczni dostawcy & $\begin{array}{l}\text { - z kapitałem zagranicznym } \\
\text { • duże i średnie prywatne firmy polskie }\end{array}$ \\
\hline & Zagraniczni odbiorcy & \begin{tabular}{|l|} 
- z kapitałem zagranicznym \\
$\cdot$ nieliczne duże i średnie prywatne firmy polskie
\end{tabular} \\
\hline & $\begin{array}{l}\text { Wspólne przedsięwzięcia } \\
\text { na zasadach partnerskich }\end{array}$ & - nie zaobserwowano \\
\hline
\end{tabular}

Źródło: Opracowanie własne na podstawie: Stryjakiewicz 1999, Michalak, Dzika 2000

Opisane powyżej dwa typy strategii adaptacyjnych dostosowują potencjał przedsiębiorstw do wielkości ich produkcji. Na adaptabilność przedsiębiorstw wpływają natomiast zmiany systemu zarządzania, zmiany struktury produkcji i nawiązanie kontaktów z partnerami zagranicznymi.

Zmiany systemu zarządzania przedsiębiorstwem obejmują sześć rodzajów strategii. Są nimi: organizacja marketingu, elastyczna organizacja produkcji, twarda i miękka restrukturalizacja, eksternalizacja produkcji oraz fuzja przedsiębiorstw i tworzenie grup kapitałowych.

Działania marketingowe polegały najczęściej na tworzeniu pozytywnego wizerunku firmy, badaniach rynku i adresowaniu swoich wyrobów do konkretnie zdefiniowanej grupy 
klientów, prowadzeniu kampanii reklamowych i promocji własnych marek oraz tworzeniu przedstawicielstw regionalnych i sieci sprzedaży. Przy czym firmy będące częścią dużych korporacji ponadnarodowych adaptowały do warunków polskich globalne strategie marketingowe korporacji.

Polskie duże i średnie przedsiębiorstwa, zwłaszcza odzieżowe, produkujące wyroby wysokiej jakości, na rynku krajowym napotykały na dwie bariery. Pierwszą był czynnik mody. Wielu klientów, zwłaszcza o wysokich dochodach, uważało wyroby znanych marek światowych za bardziej prestiżowe niż wyroby marek polskich. Drugą barierą jest pauperyzacja wielu potencjalnych klientów. Bariery te próbowano pokonać trzema sposobami: kreowaniem wizerunku własnej marki jako symbolu zamożności i sukcesu, sprzedażą swoich wyrobów pod nazwami marek producentów zagranicznych albo przeznaczaniem różnych wyrobów dla grup klientów różniących się dochodami, gustami i potrzebami. Próby sprzedaży polskiej odzieży za granicą napotykały natomiast na barierę wysokich kosztów działań marketingowych ${ }^{8}$. Eksport wyrobów pod własną marką w 1998 roku był szacowany tylko na około 1-2\% całego eksportu produkcji odzieżowej (Margas 1998). Przedsiębiorstwa polskie decydowały się wobec tego na przerób uszlachetniony. Nawiązana w ten sposób współpraca umożliwiała niekiedy sprzedaż własnych wyrobów pod nazwami marek obcych producentów i przez ich sieci sprzedaży.

Strategie twardej i miękkiej restrukturalizacji stosowano w byłych przedsiębiorstwach państwowych, po wykupieniu ich przez kapitał zagraniczny. Umożliwiało to modernizację produkcji i wprowadzenie elastycznych form jej organizacji. Działania określane jako miękka restrukturalizacja były stosowane również przez część dużych prywatnych przedsiębiorstw polskich powstałych po 1989 roku. Działania te pomagały zwiększyć adaptabilność tych firm.

Strategie eksternalizacji produkcji, outsourcingu i tworzeniu firm typu spin off były często związane z omawianymi wyżej strategiami pozbywania się produkcyjnych środków trwałych, likwidacji filii i zbędnych działów produkcji. Konsekwencją powyższych procesów było często powstawanie nowych firm. Były one tworzone przez przedsiębiorstwo macierzyste albo samorzutnie, przez zwalnianych pracowników. Powstałe w ten sposób nowe przedsiębiorstwa przejmowały od firmy macierzystej budynki i maszyny. Nowe przedsiębiorstwa, tworząc z firmą macierzystą powiązania konkurencji i współpracy, przejmowały część jej łańcucha produkcji i świadczyły usługi produkcyjne na jej rzecz. Jednocześnie nowo powstałe firmy próbowały uzupełniać przejętą od firmy macierzystej sieć odbiorców.

Niezbyt częstym rodzajem działań adaptacyjnych było tworzenie grup kapitałowych (Sołtysiński 1994). Celem tworzenia grup kapitałowych jest poprawa sytuacji finansowej firmy, zapewnienie jej bezpiecznego rozwoju w perspektywie długookresowej i zajęcie silniejszej pozycji na rynku (Stryjakiewicz, Wajda 2003).

W okresie badawczym istniały w Łodzi dwa rodzaje grup kapitałowych. Pierwszą z nich były grupy tworzone przez duże łódzkie firmy odzieżowe. Grupy te, jak piszą T. Stryjakiewicz i J. Wajda (2003, s. 29), „mają rodowód w przedsiębiorstwach socjalistycznych” i „zdołały w gospodarce planowej zbudować duży potencjał gospodarczy, a po 1989 r. okazały się zdolne, niejednokrotnie dzięki swej monopolistycznej pozycji i powiązaniom z ośrodkami

${ }^{8}$ Według informacji uzyskanej w przedsiębiorstwie Wólczanka S.A., wstępna faza kampanii reklamowej kosztuje w krajach Europy Zachodniej około $10 \mathrm{mln}$ USD. Po zakończeniu tej fazy marka jest rozpoznawana pośród innych, ale nie jest kojarzona z konkretnym produktem i jego jakością. Sprzedaż produktu umożliwia dopiero następna faza kampanii reklamowej. 
władzy, do przestawienia się na tory gospodarki rynkowej”. W grupach tego rodzaju spółki dominujące nie tworzyły nowych spółek zależnych, lecz przejmowały przedsiębiorstwa już istniejące. Słabościami omawianych grup była najczęściej kryzysowa sytuacja podmiotów dominujących w momencie tworzenia grupy, słabość finansowa spółek zależnych, brak ich dywersyfikacji branżowej oraz obecność w strukturze akcjonariatu dość dużych pakietów $\mathrm{NFI}^{9}$. Brak spółek w innych branżach niósł ryzyko w sytuacji załamania się popytu na rynku odzieżowym przy zadłużeniu przemysłu lekkiego i jego niskiej rentowności ${ }^{10}$. Ponadto omawiane grupy były nieumiejętnie zarządzane m.in. poprzez dążenie do nadmiernej centralizacji i rozbudowę powiązań pionowych.

Grupy kapitałowe drugiego rodzaju były budowane od podstaw po 1989 roku. Unikały one gospodarki typowo surowcowej, miały zdolność do kreowania innowacji oraz wykorzystywały przewagę konkurencyjną kraju (por. Stryjakiewicz, Wajda 2003).

Strategie czwartego typu (tab. 1), tj. ograniczenie asortymentu, wzrost jakości oraz wprowadzanie nowoczesnego wzornictwa i technologii, opisano dokładniej w części poświęconej studiom przypadków. W tym miejscu należałoby wspomnieć, że import wysokiej jakości tkanin przez przemysł odzieżowy przyczynił się do upadku łódzkiego włókiennictwa. Przykładem ograniczania asortymentu była produkcja ograniczonej liczby wyrobów, przeznaczonych dla starannie wybranej grupy klientów. Firmy odzieżowe średniej wielkości wprowadzały natomiast na rynek tylko dwie kolekcje rocznie (Torański 2002a). Większa liczba modeli, przy ograniczonym popycie, mogłaby zmniejszyć wielkość sprzedaży każdego z nich.

Trzecim rodzajem strategii zmieniającej strukturę produkcji przedsiębiorstwa jest przerób uszlachetniony. Jednocześnie ten rodzaj działań można potraktować jako sposób nawiązania stałych kontaktów z partnerami zagranicznymi (por. tab. 1). Przerób uszlachetniony, na ogół na zlecenie producentów z Niemiec, Francji czy Włoch, stosuje wiele zakładów różnej wielkości, głównie odzieżowych. Działalność taka stanowi do 60\% produkcji dużych łódzkich firm odzieżowych. Część zakładów tej branży została nawet założona przez zagranicznych przedsiębiorców w celu prowadzenia tego typu wytwórczości.

Przerób uszlachetniony przynosi pewne korzyści stosującym go zakładom. Potencjał produkcyjny może być w pełni wykorzystany, co umożliwia przetrwanie firmy i zachowanie miejsc pracy. Ograniczane są koszty związane z działalnością projektową i zaopatrzeniem. Zagraniczny zleceniodawca (właściciel) zapewnia również rynek zbytu. Ponadto tego typu współpraca z firmami zagranicznymi pozwala czasami korzystać z ich zagranicznych sieci dystrybucji, technologii i know how.

Przerób uszlachetniony jest jednak uważany za najmniej rentowną formę produkcji odzieżowej ${ }^{11}$. Przedsiębiorstwa mają ograniczone możliwości samodzielnej adaptacji, a wielkość i struktura produkcji zależą od decyzji zagranicznego właściciela lub zleceniodawcy. Po 1995 roku, ze względu na niższe koszty pracy, przerób uszlachetniony zaczęto masowo przenosić z Polski do Bułgarii, Rumunii, krajów poradzieckich i Jugosławii. Proces ten jest ogra-

${ }^{9}$ Według T. Rachwała (2002), zmiany własnościowe w ramach programu NFI należy uznać za najmniej efektywne. Spowodowane to było obecnością w tym programie stosunkowo słabych finansowo firm. Brak środków inwestycyjnych ograniczał ich restrukturyzację.

${ }^{10}$ Jak podaje D. Margas (1998), w 1998 rentowność produkcji odzieży i dodatków do niej wynosiła 1,88\%, natomiast rentowność produkcji wyrobów z dzianin wynosiła -1,54\%.

${ }^{11}$ Jak podaje D. Margas (1998), w 1998 roku rentowność kontraktów na przerób uszlachetniony nie przekraczała $2 \%$, a często była bliska zera. 
niczony jedynie kwalifikacjami pracowników ${ }^{12}$. Jednocześnie przerób uszlachetniony jest mało korzystną formą współpracy zagranicznej. Sprowadza się ona do montażu, natomiast najbardziej wartościowe, wiedzochłonne elementy łańcucha produkcji są zlokalizowane za granica. W konsekwencji przepływ kapitału, technologii i know how jest jednostronny (por. Stryjakiewicz 1999). Powyższe zjawiska są zagrożeniem dla rynku pracy i rozwoju danej branży oraz utrudniają adaptabilność gospodarki miasta.

Próby pozyskania zagranicznych odbiorców przez sprywatyzowane przedsiębiorstwa państwowe opierały się na przerobie uszlachetnionym albo odnawianiu kierunków eksportowych sprzed 1989 roku. Odmienną strategię, porównywalną z modelem ekspansji przedsiębiorstw ponadnarodowych (por. Stryjakiewicz 1999), stosowały firmy powstałe po 1989 roku. Po uzyskaniu stabilnej pozycji na rynku polskim wspomniane firmy rozpoczęły ekspansję zagraniczną od tworzenia przedstawicielstw handlowych i sieci dystrybucji. Następnym krokiem były próby przenoszenia za granicę części produkcji. Ekspansja była prowadzona początkowo w byłych państwach socjalistycznych. Dopiero w następnej kolejności próbowano z własną marką wejść na dużo trudniejsze rynki Europy Zachodniej.

Większość małych i około 30\% średnich firm w Łodzi stosowała w okresie badawczym bardzo ograniczone działania adaptacyjne. Obejmowały one jedynie elastyczne formy zatrudnienia.

Wydaje się, że istniały dwie przyczyny biernej postawy opisywanych firm wobec sygnałów rynkowych. Pierwszą z nich był brak wiedzy przedsiębiorców na temat elastycznego gospodarowania, marketingu i zarządzania. Ograniczanie asortymentu było rezultatem niewielkiego potencjału produkcyjnego firm, a nie ich przemyślanej strategii. Druga przyczyna była związana z małą skalą produkcji i cechami klientów, dla których ta produkcja była przeznaczona. Byli to klienci o niskich dochodach i małych wymaganiach co do jakości i wzornictwa wyrobów. Wobec tego firmy zapożyczały wzory od siebie nawzajem albo powielały i podrabiały wzory marek zagranicznych. Sprzedaż tych wyrobów odbywała się na bazarach, poprzez sieci hipermarketów albo małych sklepów.

\section{TYPOLOGIA FORM ADAPTACJI}

Według modelu sposobów regulacji przedsiębiorstwa przemysłowego (Asheim, Heraldsen 1991; Smith 1995), strategie adaptacyjne regulując relacje sieciowe przedsiębiorstwa wpływają na jego adaptabilność. Strategie adaptacyjne obejmują: strategie integracji sieci dostawców i odbiorców, strategie konkurencji i współpracy oraz relacje z systemem finansowym i systemem regulacji państwowych (por. Stryjakiewicz 1999).

Na podstawie powyższego modelu A. Smith (1995) dokonał typologii form adaptacji przestrzennej przedsiębiorstw przemysłowych w warunkach transformacji systemowej. T. Stryjakiewicz (1999) przystosował tę typologię do warunków polskich W przedstawionej poniżej typologii form adaptacji łódzkich przedsiębiorstw przemysłowych, oprócz adaptacji dezindustrializującej, paternalistycznej i globalizującej wydzielonych przez T. Stryjakiewicza (1999), wyróżniono dwa typy dodatkowe: adaptację lokalną i przejściową (tab. 2). Cechy, przyczyny i skutki adaptacji dezindustrializującej, paternalistycznej i globalizującej były

\footnotetext{
${ }^{12}$ W 1997 roku firma Hugo Boss zrezygnowała z usług producentów ukraińskich, z powodu ich niskiej jakości, i ponownie zleciła produkcję przedsiębiorstwu Próchnik S.A.
} 
w przemyśle łódzkim w większości identyczne z opisanymi przez T. Stryjakiewicza (1999). Dlatego formy te nie zostały uwzględnione w tabeli 2 .

Tabela 2. Lokalna i przejściowa forma adaptacji łódzkich zakładów przemysłowych

\begin{tabular}{|c|c|c|c|}
\hline \multicolumn{2}{|r|}{$\begin{array}{c}\text { Forma } \\
\text { adaptacji }\end{array}$} & Lokalna & Przejściowa \\
\hline \multicolumn{2}{|c|}{$\begin{array}{c}\text { Rodzaj } \\
\text { przedsiębiorstw }\end{array}$} & - małe i średnie zakłady polskie & $\begin{array}{l}\text { - średnie i duże zakłady polskie lub z kapita- } \\
\text { łem mieszanym, } \\
\text { • część sprywatyzowanych dawnych dużych } \\
\text { zakładów państwowych }\end{array}$ \\
\hline \multirow{2}{*}{  } & $\begin{array}{c}\text { Sieci } \\
\text { dostawców }\end{array}$ & $\begin{array}{l}\text { - dostawcy krajowi lub surowce } \\
\text { importowane nabywane przez } \\
\text { pośredników, } \\
\text { • niska jakość i cena surowców }\end{array}$ & $\begin{array}{l}\text { - wzrost jakości surowców, } \\
\text { - import, } \\
\text { • selekcja dostawców krajowych pod wzglę- } \\
\text { dem elastyczności i jakości dostaw }\end{array}$ \\
\hline & $\begin{array}{c}\text { Sieci } \\
\text { odbiorców }\end{array}$ & $\begin{array}{l}\text { - rynki lokalne - sprzedaż poprzez } \\
\text { sieć małych sklepów i bazarów, } \\
\text { - rynki zagraniczne (gł. kraje post- } \\
\text { radzieckie) przez sprzedaż } \\
\text { w systemie bazarowym, } \\
\text { - sprzedaż w sieciach hipermar- } \\
\text { ketów }\end{array}$ & $\begin{array}{l}\text { - budowanie własnych kanałów dystrybucji, } \\
\text { - umocnienie na rynku krajowym, potem } \\
\text { ekspansja na rynki Europy Środkowo- } \\
\text { Wschodniej (ewentualnie próba ich odbu- } \\
\text { dowy), } \\
\text { • próby wejścia na rynki Europy Zachodniej } \\
\text { lub przerób uszlachetniony }\end{array}$ \\
\hline \multicolumn{2}{|c|}{$\begin{array}{c}\text { Strategie } \\
\text { konkurencji } \\
\text { i współpracy }\end{array}$} & $\begin{array}{l}\text { - brak relacji z innymi producen- } \\
\text { tami }\end{array}$ & $\begin{array}{l}\text { - konkurencja na rynku polskim; próby kon- } \\
\text { kurencji na rynku globalnym, } \\
\text { • brak silnych relacji z innymi producenta- } \\
\text { mi, } \\
\text { • próby współpracy przy promocji marki na } \\
\text { rynku polskim, } \\
\text { - przerób uszlachetniony }\end{array}$ \\
\hline \multirow{3}{*}{ 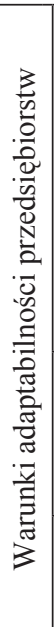 } & 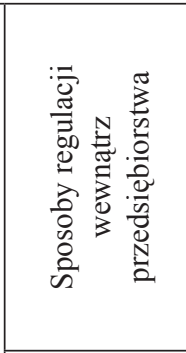 & $\begin{array}{l}\text { - elastyczne formy organizacji } \\
\text { produkcji, } \\
\text { • często zatrudnianie „na czarno”, } \\
\text { - brak własnych wzorów; wyroby } \\
\text { podrabiane i zapożyczane, } \\
\text { • brak marketingu, } \\
\text { - ograniczona grupa klientów }\end{array}$ & $\begin{array}{l}\text { - redukcja zatrudnienia, elastyczne formy } \\
\text { organizacji produkcji, } \\
\text { • opracowanie własnych technologii i pro- } \\
\text { jektów, } \\
\text { • tworzenie własnych strategii marketingo- } \\
\text { wych opartych często na wzorach zagra- } \\
\text { nicznych, } \\
\text { - zróżnicowane grupy klientów, } \\
\text { - próby tworzenia grup kapitałowych }\end{array}$ \\
\hline & $\begin{array}{l}\text { Regulacje } \\
\text { państwowe }\end{array}$ & $\begin{array}{l}\text { - wspieranie rozwoju MSP, infra- } \\
\text { struktury oraz instytucji otoczenia } \\
\text { biznesu, }\end{array}$ & $\begin{array}{l}\text { - wspieranie rozwoju MSP, infrastruktury } \\
\text { oraz instytucji otoczenia biznesu, } \\
\text { • wycofywanie się z bezpośredniego inter- } \\
\text { wencjonizmu }\end{array}$ \\
\hline & $\begin{array}{c}\text { Relacje } \\
\text { z systemem } \\
\text { finansowym }\end{array}$ & $\begin{array}{l}\text { - ograniczone pożyczki i kredyty, } \\
\text { • zadłużenie wobec państwa }\end{array}$ & $\begin{array}{l}\text { - pożyczki i kredyty, } \\
\text { - transakcje kapitałowe }\end{array}$ \\
\hline
\end{tabular}

Źródło: Opracowanie własne na podstawie Stryjakiewicz 1999

Dezindustrializującą i paternalistyczną formę adaptacji stosowały przedsiębiorstwa państwowe i większość jednoosobowych spółek Skarbu Państwa branży włókienniczej, ma- 
szynowej i odzieżowej. Ze względu na ich małą siłę przetargową, adaptacja paternalistyczna w większości przypadków zmieniała się w formę adaptacji dezindustrializującej. Przyczyniło się to do likwidacji wielu zakładów i dużej dynamiki spadku zatrudnienia w przemyśle Łodzi (por. m.in.: Marczyńska-Witczak 1996, Markowski, Stawasz 1997; Strategia... 1999; Marszał, May 2002).

Globalizującą formę adaptacji stosowały przede wszystkim zakłady należące do kapitału zagranicznego. Część z nich była włączana w sieć powiązań międzynarodowych i procesy globalizacji. Taką strategię stosowały m.in. omówione wyżej zakłady ABB Elta, producent ostrzy do golenia Gilette Poland czy produkujący materiały wełniane East West Spinning. Niektóre koncerny ponadnarodowe oraz przedsiębiorstwa zagraniczne średniej wielkości stosowały jednak kolonialny lub zastępujący import typ strategii lokalizacyjnych (por. Stryjakiewicz 1999). Przykładami takich strategii są m.in. Coca-Cola, VF Manufacturing produkujący odzież marki „Wrangler” i „Lee” oraz firmy odzieżowe nastawione na przerób uszlachetniony.

W łódzkich firmach stosujących adaptację globalizującą zaobserwowano pewne różnice w porównaniu z cechami podanymi przez T. Stryjakiewicza (1999):

1) w strategiach integracji sieci dostawców:

a) włączanie zakładu w istniejącą sieć zaopatrzenia koncernu,

b) szukanie dostawców wśród firm polskich i ich selekcja pod względem jakości i elastyczności dostaw,

2) w strategiach integracji sieci odbiorców: włączanie przedsiębiorstw w istniejącą sieć dystrybucji,

3) w sposobach regulacji wewnątrz przedsiębiorstwa:

a) sporadyczne lokalizowanie w Łodzi działów badawczo-rozwojowych,

b) przenoszenie gotowych strategii marketingowych i dostosowywanie ich do rynku polskiego.

Dwa pierwsze rodzaje strategii umożliwiały elastyczną organizację produkcji i orientowały przedsiębiorstwo na rynek globalny. Przyczyniały się one również do powstawania przemysłowych struktur sieciowych i pożądanych efektów mnożnikowych w gospodarce miasta. Ponadto takie działania wraz z lokalizacjami greenfields świadczyły o kształtowaniu wyposażenia terytorialnego przez koncerny ponadnarodowe (Grabher 1993). Wskazywało to na ich zamiar dłuższej działalności na danym obszarze. Trzecia z wymienionych strategii mogła mieć natomiast negatywne skutki. Pozostawienie wiedzochonnych elementów łańcucha produkcji poza firmami łódzkimi sprowadzało je do roli odtwórcy gotowych wzorów. Ograniczało to adaptabilność tych firm i obniżało jakość wyposażenia społecznego Łodzi.

Duże i średnie firmy powstałe po 1989 roku oraz część sprywatyzowanych dawnych zakładów państwowych stosowały formę adaptacji nazwaną w artykule przejściową. W opinii autora jest to forma pośrednia między adaptacją paternalistyczną, lokalną albo dezindustrializującą a adaptacją globalizującą. Firmy stosujące adaptację przejściową miały znaczenie ponadregionalne, ale skala ich produkcji i stosowanych strategii adaptacyjnych była mniejsza niż firm stosujących adaptację globalizującą. Omawiana forma adaptacji pozwalała firmom zwiększyć adaptabilność i stopniowo przystosować się do konkurencji globalnej.

Ważnym, w opinii autora, elementem tej formy adaptacji było tworzenie własnych projektów wyrobów, rozwiązań technologicznych i marketingowych oraz sieci dostawców i odbiorców. Słabością tej formy adaptacji był natomiast brak silnych relacji z innymi producentami. 
Omawianą formę adaptacji stosowały m.in. powstałe po 1989 roku firmy kosmetyczne Kolastyna, Loki i Venita, odzieżowe Hexeline, Ola Styl Studio, czy też produkujący materiały budowlane Atlas S.J. Adaptację przejściową próbowały również stosować dawne przedsiębiorstwa państwowe przemysłu odzieżowego, np.: Olimpia S.A., Wólczanka S.A., Próchnik S.A. i Telimena S.A.

W przypadku tych ostatnich przedsiębiorstw adaptacja przejściowa była mniej skuteczna niż w przypadku firm prywatnych, tworzonych od podstaw w warunkach gospodarki rynkowej. Przyczynami były: początkowe znaczne niedostosowanie dawnych państwowych firm do warunków gospodarki rynkowej, mało rentowny rodzaj produkcji oraz brak umiejętności kadry menadżerskiej. W przypadku firmy Telimena S.A. do powyższych problemów dołączyły skutki nieprzemyślanej relokacji, co w rezultacie doprowadziło do adaptacji dezindustrializującej. Fakt ten wskazuje, że nieskuteczność przejściowej formy adaptacji prowadzi do adaptacji dezindustrializującej albo lokalnej.

Większość małych i średnich badanych zakładów przemysłowych, głównie włókienniczo-odzieżowych, stosowała formę adaptacji nazwaną przez autora lokalną. Zdaniem autora, adaptacja lokalna jest najmniej skuteczną, obok adaptacji dezindustrializującej, formą adaptacji zakładów przemysłowych. Ogranicza ona aktywność przedsiębiorstw do rynku lokalnego. Firmy nie włączają się w procesy globalizacji i są mało adaptabilne. Działalność tylko na rynku lokalnym nie zapewnia im rozwoju i trwania w perspektywie długookresowej. Wydaje się, że największymi słabościami omawianej formy adaptacji są:

- brak własnego wzornictwa i imitacja, często nielegalna, obcych wzorów;

- stosowanie przestarzałych technologii i niska jakość produkcji;

- brak relacji z innymi przedsiębiorstwami miasta i regionu;

- słabo rozwinięta sieci dystrybucji;

- końcowa pozycja w łańcuchu produkcji, co powoduje, że firmy były odbiorcami, a nie dostawcami dużych przedsiębiorstw.

Adaptacja lokalna różni się od adaptacji dezindustrializującej m.in. następującymi cechami:

- wielkością firm; adaptację lokalną stosują na ogół firmy małe i średnie;

- czasem powstania firm, po 1989 roku, co spowodowało brak obciążeń wadami strukturalnymi z okresu gospodarki nakazowo-rozdzielczej;

- skutecznością; adaptacja lokalna nie musi prowadzić do likwidacji firm.

Analiza materiału empirycznego i powyższe rozważania skłaniają autora do sformułowania trzech rodzajów wniosków.

1. Wnioski dotyczące przyczyn i skutków podejmowanych działań adaptacyjnych:

- Strategie adaptacyjne redukujące koszty były najważniejsze w początkowym okresie transformacji. Ich stosowanie wynikało m.in. z pracochłonnej i mało nowoczesnej struktury przemysłu łódzkiego.

- Redukcja kosztów, niezbędna do przetrwania przedsiębiorstw i wprowadzenia innych strategii adaptacyjnych, nie wystarczała jednak do zapewnienia firmom adaptabilności.

- Warunkiem adaptabilności przedsiębiorstw w perspektywie długookresowej było zastosowanie strategii rzeczywiście, a nie pozornie, zmieniających system zarządzania. Strategie te wprowadzały elastyczne formy organizacji produkcji typu postfordowskiego. 
- Adaptacja dużych przedsiębiorstw państwowych, nawet po procesach prywatyzacji, często była nieskuteczna. Przyczyny nieskuteczności działań adaptacyjnych tych przedsiębiorstw były złożone i obejmowały:

- opisane w literaturze bariery rozwoju przemysłu łódzkiego odziedziczone po gospodarce nakazowo-rozdzielczej (m.in. Jewtuchowicz 1993; MarczyńskaWitczak 1996; Markowski, Stawasz 1997; Markowski, Marszał 1999; Marszał, May 2002);

- niską rentowność reprezentowanych przez przedsiębiorstwa branż;

- pasywną reakcję zakładów na zmianę warunków gospodarowania w początkowym okresie transformacji systemowej;

- stosowanie dezindustrializujących lub paternalistycznych form adaptacji w okresie późniejszym;

- brak wiedzy na temat innych niż redukcja kosztów strategii adaptacyjnych oraz mentalność kadry zarządzającej, którą można określić jako paternalistyczną (por. m.in.: Duché 1997; Strategia... 1999);

- Adaptacja dawnych przedsiębiorstw państwowych, przejętych przez zagranicznych inwestorów, była na ogół skuteczna. Jak wskazuje jednak przykład firmy DaewooFonica sp. z.o.o., ostateczny rezultat adaptacji zależał od sytuacji ekonomicznej inwestora zagranicznego.

- Skuteczna była również adaptacja dużych i średnich firm z kapitałem polskim, powstałych po 1989 roku, stosujących przejściową formę adaptacji.

- Lokalna forma adaptacji bywała skuteczna w perspektywie krótkookresowej, nie dawała jednak trwałych podstaw adaptabilności firm. Stosujące ją, małe i średnie przedsiębiorstwa G. Duché (1997) nazywa „słabo skoordynowanym środowiskiem przedsiębiorczości”.

- Uogólniając powyższe wnioski można stwierdzić, że rodzaje działań adaptacyjnych łódzkich zakładów przemysłowych zależą od ich przeszłości, w tym genezy (Belka i in. 1995), wielkości, rodzaju produkcji, pochodzenia kapitału i formy własności.

2. Wnioski dotyczące przestrzennych skutków działań adaptacyjnych:

- Strategie adaptacyjne polegające na ograniczeniu zajmowanych przestrzeni produkcyjnych i likwidacji filii zwiększały podaż wolnych terenów przemysłowych. Zjawisko to wraz ze strategiami relokacyjnymi wpłynęło bezpośrednio na rozmieszczenie zakładów przemysłowych w mieście.

- Sprzedaż zbędnych maszyn i urządzeń wraz z redukcjami zatrudnienia oraz strategie eksternalizacji i outsourcingu wpływały na rozwój sektora MSP. Wraz ze zmianami rozmieszczenia zakładów powodowało to różnokierunkowe zmiany przestrzennej struktury branżowej i wielkościowej przemysłu.

- Jednocześnie strategie eksternalizacji i outsourcingu prowadziły do ukształtowania się sieci konkurencji i współpracy między firmami powstałymi na skutek stosowania tych strategii a ich firmami macierzystymi i innymi podmiotami gospodarczymi.

- Strategie zmieniające system zarządzania i strukturę produkcji przedsiębiorstwa również kształtowały nowe sieci powiązań.

- Pomimo tworzenia się nowych sieci powiązań, w łódzkim przemyśle nie wytworzyły się jednak silne struktury sieciowe. Utrudniało to powstanie marshallowskiego okręgu przemysłowego (por.: Domański 1992; Stryjakiewicz 1999) i zmniejszało 
adaptabilność poszczególnych firm oraz przemysłu całego miasta. Zdaniem autora, brak silnych struktur sieciowych w Łodzi wynika:

- ze słabości zakładów powstałych na skutek eksternalizacji i słabo skoordynowanego środowiska przedsiębiorczości (Duché 1997);

- $\quad \mathrm{z}$ braku ważnych elementów wyposażenia społecznego, takich jak środowisko zaufania i kultura korporacyjna (Granovetter 1985).

3) Wnioski dotyczące związków stosowanych strategii adaptacyjnych z procesami globalizacji:

- Formy adaptacji większości łódzkich przedsiębiorstw przemysłowych wskazują na słabo zaawansowane procesy globalizacji przemysłu łódzkiego.

- Niektóre cechy adaptacji przejściowej, zwłaszcza tworzenie od podstaw grup kapitałowych i tworzenie sieci dystrybucji na rynkach Europy Zachodniej, mogą oznaczać powolne wchodzenie gospodarki łódzkiej w trzeci etap procesu globalizacji (Stryjakiewicz 1999; Stryjakiewicz, Wajda 2003).

\section{Literatura}

Aglietta M., 1979, A theory of capitalist regulation, the US experience, London.

Asheim B.T., Heraldsen T., 1991, Methodological and theoretical problems in economic geography, „Norsk Geogr. Tidasskr.”, 45.

Belka M., Estrin S., Schaffer M.E., Singh I.J., 1995, Enterprise adjustment in Poland: evidence from a survey of 200 private, privatised and state-owned firms, „Discussion Paper”, no 233, LSE, Centre for Econ. Performance, London.

Boyer R., 1990, Thee regulation school, a critical introduction, New York.

Conti S., 1993, The network perspective in industrial geography. Towards a model, „Geogr. Annaler”, no $75 \mathrm{~B}$, vol. 3.

Duché G., 1997, Lokalny system produkcyjny w Łodzi i regionie łódzkim (czyli słabo skoordynowane środowisko przedsiębiorczości), [w:] A. Jewtuchowicz (red.), Środowisko przedsiębiorczości, innowacje a rozwój terytorialny, Łódź.

Grabher G. (ed), 1993, The embedded firm. On the socioeconomics of industrial networks, LondonNew York.

Granovetter M., 1985, Economic action and social structure, the problem of embeddedness, „American Journal of Sociology", 91, 3.

Håkansson H., Johanson J., 1993, The network as a governance structure: interfirm cooperation beyond markets and hierarchies, [in:] G. Grabher (ed.), The embedded firm. On the socioeconomics of industrial networks, London-New York.

Hamilton F.E.I., Linge G.J.R. (eds.), 1979, Industrial systems, London.

Jewtuchowicz A., 1993, Podstawowe kierunki i problemy restrukturyzacji Łodzi i województwa łódzkiego, [w:] A. Jewtuchowicz (red.), Rozwój lokalny i regionalny w okresie transformacji gospodarki polskiej, Łódź.

Marczyńska-Witczak E., 1996, Zmiany struktury gospodarczej Łodzi, [w:] W. Michalski (red.), Transformacja społeczno-gospodarcza Łodzi na tle regionu, Łódź.

Marczyńska-Witczak E., 2001, Procesy dezindustrializacji przestrzennej w latach dziewięćdziesiatych na przykładzie Łodzi, [w:] Z. Zioło (red.), Problemy przemian struktur przestrzennych przemystu, Prace Komisji Geografii Przemysłu PTG, nr 2, Warszawa-Kraków.

Margas D., 1998, Uwolnić się od dlugu, „Rzeczpospolita”, 22.12.1998.

Markowski T., Marszał T., 1999, Recovering economy of a region in transition - the case of Łódź Industrial Agglomeration (Poland), „European Spatial Research and Policy”, vol. 6, no. 1/1999, Łódź. 
Markowski T., Stawasz D., 1997, Łódź i region - przyczyny upadku i rozwoju, [w:] G. Gorzelak (red.), Przemiany polskiej przestrzeni, Studia Regionalne i Lokalne, nr 19 (52), Warszawa.

Marszał T., May J., 2002, Adaptation Processes in Polish Industry in Conditions of the Market Economy, as Exemplified by the City of Łódź, [in:] R. Domański (ed.), Cities and Regions in an Enlarging European Union, Studia Regionalia, vol. 10, Warszawa.

May J., 2000, Changes in spatial concentration of industry in Łódź in the 1990s, [in:] T. Marszał (ed.), Local economy and Urban Development in Poland, Łódź.

Michalak M.J., Dzika U., 2000, Problemy restrukturyzacji gospodarki województwa tódzkiego z uwzględnieniem zmian form własności, [w:] M. Sobczyński, W. Michalski (red.), Województwo tódzkie na tle przemian administracyjnych Polski. W osiemdziesiata rocznicę utworzenia województwa, Łódź.

Rachwał T., 2002, Proces restrukturyzacji przedsiębiorstw przemystowych $w$ Polsce poludniowo-wschodniej (na wybranych przykładach), [w:] Z. Zioło (red.), Problemy transformacji struktur przemysłowych, Prace Komisji Geografii Przemysłu PTG, nr 4, Warszawa-Kraków-Rzeszów.

Smith A., 1995, Regulation theory, strategies of enterprise integration and the political economy of regional economic restructuring in Central and Eastern Europe: the case of Slovakia, „Regional Studies", no. 29, vol. 8.

Sołtysiński S., 1994, Zgrupowania spółek. Zarys problematyki prawnej, „Kwartalnik Prawa Gospodarczego", z. 3.

„Strategia rozwoju miasta Łodzi, cz. I. Diagnoza stanu zainwestowania miasta Łodzi”. Zespół pod kier. A. Jewtuchowicz, maszynopis, Wydział Strategii UMŁ, luty 1999, Łódź.

Stryjakiewicz T., 1999, Adaptacja przestrzenna przemystu $w$ Polsce $w$ warunkach transformacji, Poznań.

Stryjakiewicz T., Wajda J., 2003, Organizacja przestrzenna grup kapitałowych jako problem badawczy geografii ekonomicznej, [w:] Z. Zioło, Z. Makieła (red.), Przemyst w procesie globalizacji, Prace Komisji Geografii Przemysłu PTG, nr 6, Warszawa-Kraków.

Torański B., 2002a, Nie ma już „polskiego Manchesteru”, „Rzeczpospolita”, nr 287 (6364), dodatek „Regiony - województwo łódzkie".

Torański B., 2002b, Energia, leki i kleje do glazury, „Rzeczpospolita”, nr 287 (6364), dodatek „Regiony - województwo łódzkie".

Walker D.F., 1975, A behavioral approach to industrial location, [in:] L. Collins, D.F. Walker (eds.), Location dynamics of manufacturing activity, London.

\section{Adaptation of industrial enterprises - the case of Lódź}

This article has two objectives. The cognitive objective is to recognize and systematize the strategies of adaptation of industrial enterprises in Łódź in the years 1992-2003. The basis for the systematic arrangement are conclusions made by T. Stryjakiewicz (1999), J. Michalak and U. Dzika (2000). The other, theoretical objective is an attempt to apply the typology of forms of space adaptation of industrial enterprises presented by T. Stryjakiewicz (1999) in order to synthesise the identified strategies. The typology of T. Stryjakiewicz transfers A. Smith's (1995) conclusions into Polish science. Its theoretical basis are theories of regulation and industrial networks.

Having studied the cases of fifteen companies, whose adaptation strategies were the most diverse or characteristic of a given branch, the author has systemized the identified adaptation procedures. There were eighteen different types of strategies falling into five categories: cost reduction, relocation, changes in management system, changes in the structure of production and contacts with foreign partners.

While trying to classify the adaptation typology forms, besides those characterized by T. Stryjakiewicz (1999), such as deindustrializing, paternalistic and global, two additional types were recognized: local and transitional adaptation. Local adaptation, applied mostly by small enterprises, limits 
their activity to the local market. Those enterprises have a small adaptability and do not participate in the process of globalization. The transitional type is common to a part of medium-sized and large enterprises with Polish capital. Owning to new technologies and organization of production, they increase their adaptability and are better suited to global competition.

The analysis has led to the conclusion that the kind of adaptation procedures taken by enterprises and also the result of those actions depend on the origin of the enterprises, their branch, size and the origin of capital. 